\title{
Příčiny poruch prosklených střech
}

\section{Fault Source of Glass Roofs}

\author{
Šárka Šilarová* \\ České vysoké učeni technické, fakulta stavebni, Praha
}

\begin{abstract}
Abstrakt
S nástupem nových konstrukčních řešení moderní architektury se postupně od 90. let minulého století čím dál tím ve větší míre začínají uplatňovat nejen velkoplošné střešní světlíky, ale i prosklené střešní pláště atrií nad prostory s trvalým pobytem lidí. Při správném tepelně technickém návrhu prosklených střech je nutno se zaměřit především na konstrukční řešení a na bezchybnou tvorbu detailů. Tento príspěvek byl publikován na XXVII. mezinárodní konferenci Expert Forensic Science 2018 ve dnech 1.-2. února 2018 v Brně.
\end{abstract}

Klíčová slova: porucha, prosklená střecha, rekonstrukce, zasklívací jednotka, podložný profil.

\section{1. ÚVOD}

Střešní pláště se skleněnou krytinou se navrhují k prosvětlení podstřešního prostoru, a to nejen u zimních zahrad, skleníků apod. Většinou se jedná o rozsáhlé střešní plochy a pasáže, kde nosnými stropními prvky jsou ocelové vazníky či rámy, jež tvoří

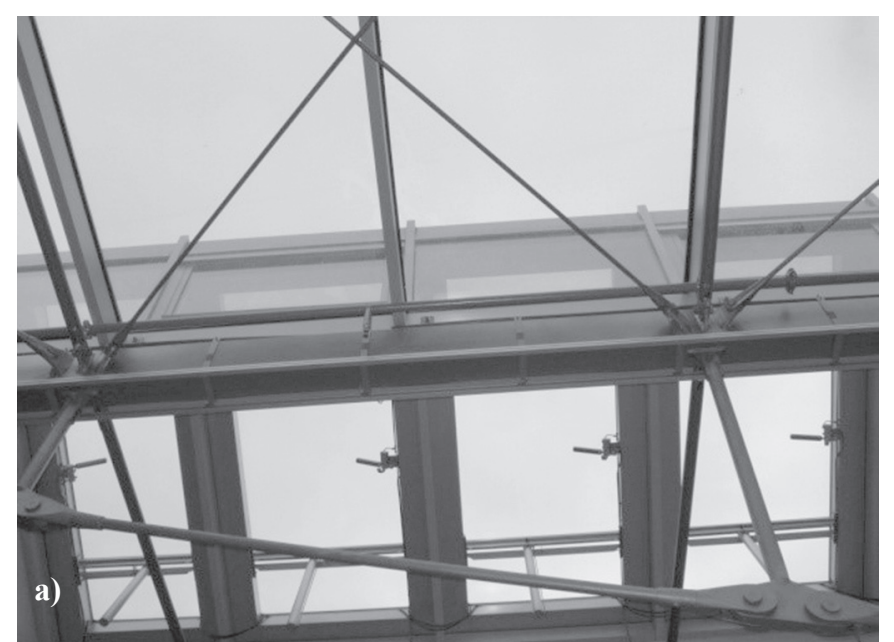

\begin{abstract}
Since the nineties and with new structural solutions of modern architecture gradually there are more and more applied not only large-size roof skylights, but roof coverings above living areas provided with glass as well. In the presented paper I will concentrate - in the first place - on structural solution of fundamental roof compositions and creation of details. The paper was published at XXVII. International conference Expert Forensic Science 2018 held on February $1^{\text {st }}-2^{\text {nd }} .2018$ in Brno.
\end{abstract}

Keywords: fault, glass roof, rekonstruction, glazing unit, underlying profile.

nosný systém pro prvky kostrového systému lehkého obvodového pláště, na kterém jsou aplikovány zasklívací jednotky, které tvoří střešní krytinu a zároveň musí zajistit i tepelně izolační vlastnosti navržené prosklené střechy. Krytina z tabulového skla se navrhuje z kombinace kaleného skla pro exteriér a bezpečnostního (lepeného) skla z interiéru. Sklo střešního pláště na základě tepelně technických

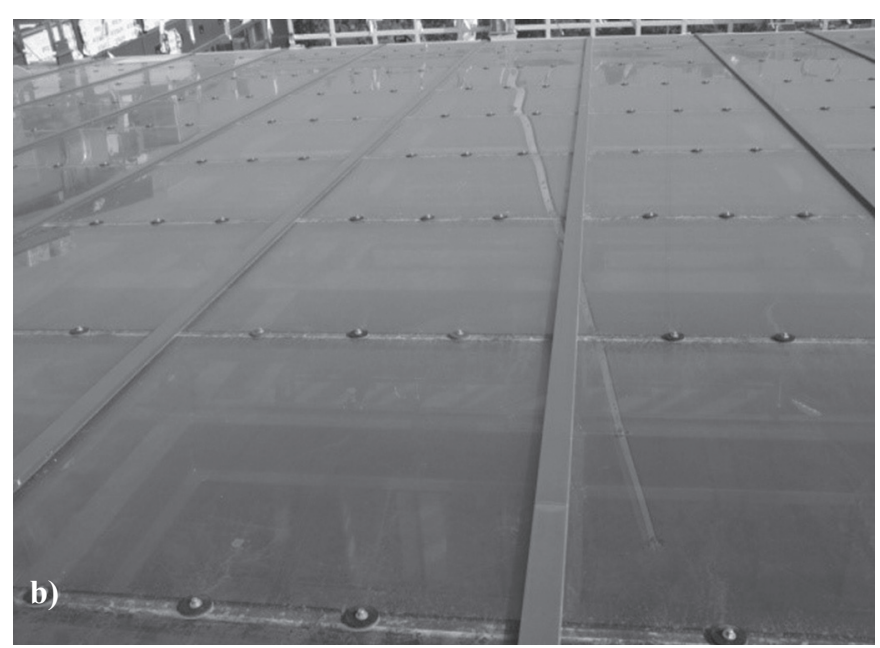

Obr. 1 Pohled na prosklený střešni plášt': a) interiér; b) exteriér.

Fig. 1 A view of the glass roof: a) interior; b) exterior.

Dodáno do redakce: 11 . 7. 2018

DOI: http://dx.doi.org./10.13164/SI.2018.3.33

Recenzní řizení: od 10. 8. do 24. 8. 2018 
požadavků se aplikuje ve formě dvojskla nebo trojskla s teplým distančním rámečkem. Vzhledem k mechanickým vlastnostem skla je nutno zajistit dokonalou dilataci skleněných tabulí ve stycích a v napojení na ostatní konstrukce v kombinaci se základní funkcí střešního pláště - vodotěsností, což je pro konstrukční řešení obtížný úkol.

Spoje a styky zasklívacích jednotek se navrhují jako volné $\mathrm{s}$ přesahem či zasunutím, anebo těsněné těsněním či pružnými tmely. V horizontálních spárách se skleněné tabule spojují pomocí speciálních profilů, jejichž velikost je závislá na sklonu krytiny.

Ke splnění závazných tepelně technických normových požadavků je nutný nový pohled a radikální úpravy konstrukčních řešení prosklených střech včetně jejich detailů.

\section{NEJČASTĚJŠÍ PORUCHY PROSKLENÝCH STŘECH}

$\mathrm{Na}$ základě zjištění vyplývajících z posuzovaných prosklených střešních plášt'ů, které vykazovaly poruchy, a proto byly podrobeny podrobné analýze, lze vytipovat nejčastější poruchy, které se na prosklených střechách opakovaně vyskytují. Jsou to tyto nedostatky:

a) nedostatečný sklon proskleného střešního pláště - sklon střechy, který je menší než $10 \%$, není bezpečným sklonem pro prosklenou krytinu. Důsledkem malého sklonu je ohrožena nejen těsnost spojů a spár zasklívacích jednotek, které tvoří střešní krytinu, ale dochází vlivem pomalého odtoku srážkové vody ze střešní plochy $\mathrm{k}$ nadměrnému hromadění nečistot na zasklívacích jednotkách, především v okolí zasklívacích spár a krycích lišt.

b) nedostatečná stabilita zasklívacích jednotek - vlivem absence nebo malého počtu nosných a distančních podložek v zasklívacích sparách dochází $\mathrm{k}$ porušení stability skel s důsledkem poruch nejen spár, ale i zasklívacích jednotek, jejichž okraj při mechanickém namáhání v kombinaci s nesilovým namáháním teplotou může iniciovat vznik prasklin skel a následné destrukce zasklívací jednotky.

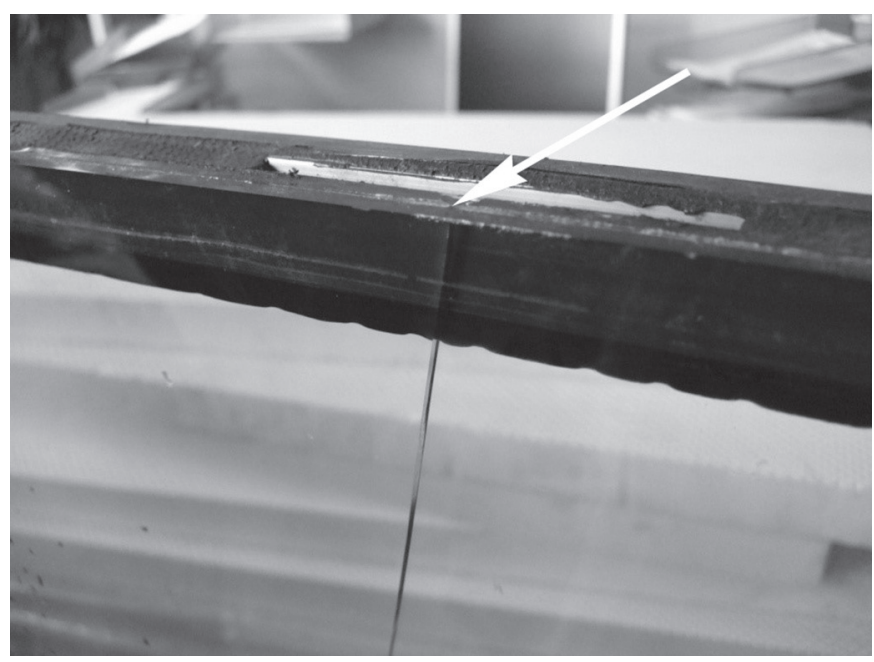

Obr. 2 Iniciace praskliny skla vlivem porušení okraje zasklívací jednotky u nosné podložky.

Fig. 2 Initiation of glass cracks as a result of breaking the edge of the glazing unit on the support pad. c) netěsnost spár a spojů - tmelené spáry a spoje jsou zpracovány v rozporu s technickými pokyny a technologickými postupy:

- podložné profily spár jsou z nevhodného materiálu,

- účinná hloubka tmelového uzávěru (spáry) nesplňuje požadavek poměru šiŕrky k výšce mocnosti tmelového uzávěru, který pro jeho bezchybnou funkci musí být roven 2/1.
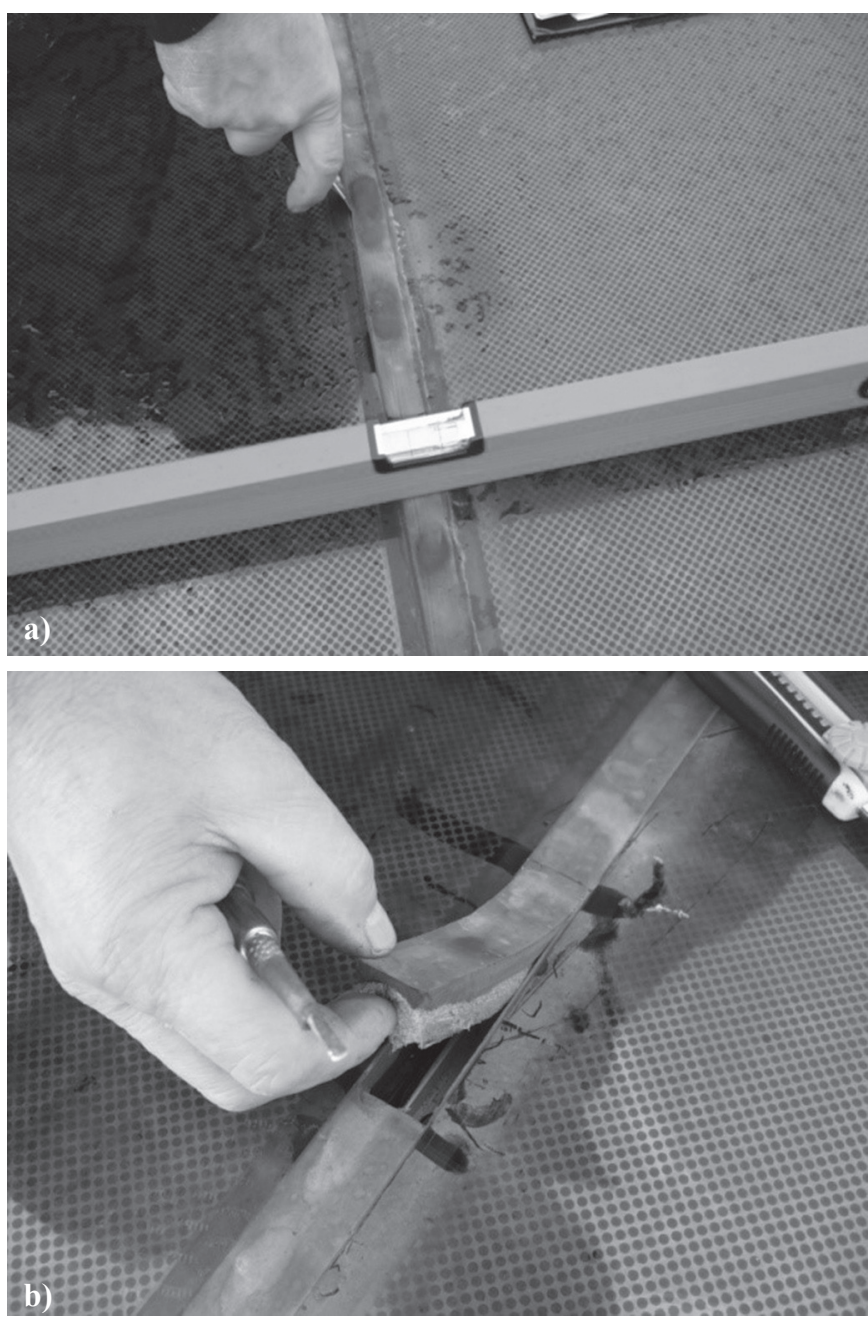

Obr. 3 Sonda ve viditelně porušené tmelené spáře: a) pohled na tmelovou spáru, která má bubliny; b) nevhodný tvar podložného profilu a malá mocnost tmelu.

Fig. 3 Probe in visibly damaged cemented joints: a) a view of a cement joint that has bubbles; b) inappropriate shape of the underlying profile and the small thickness of the sealant.

d) netěsnost spádových systémových lišt - lištované spoje jsou zpracovány z odpovídajícího materiálu, jeho zabudování je provedeno $v$ rozporu s technickými zásadami montáže spádových lišt. Pryžová systémová těsnění jsou dodatečně doplňována tmelením na povrchu proskleného střešního pláště.

e) netěsnost prostupujících konstrukcí a napojení oplechování - zabudování kování vykazuje netěsnosti a je opracováno často opakovaným nepřípustným tmelením. V napojení střešního pláště na oplechování je podklad oplechování nestabilní, tím neumožňuje plynulý odtok vody. Spáry mezi plechem a proskleným pláštěm jsou namáhány tvarovými změnami a ve svém důsledku nejsou těsné. 

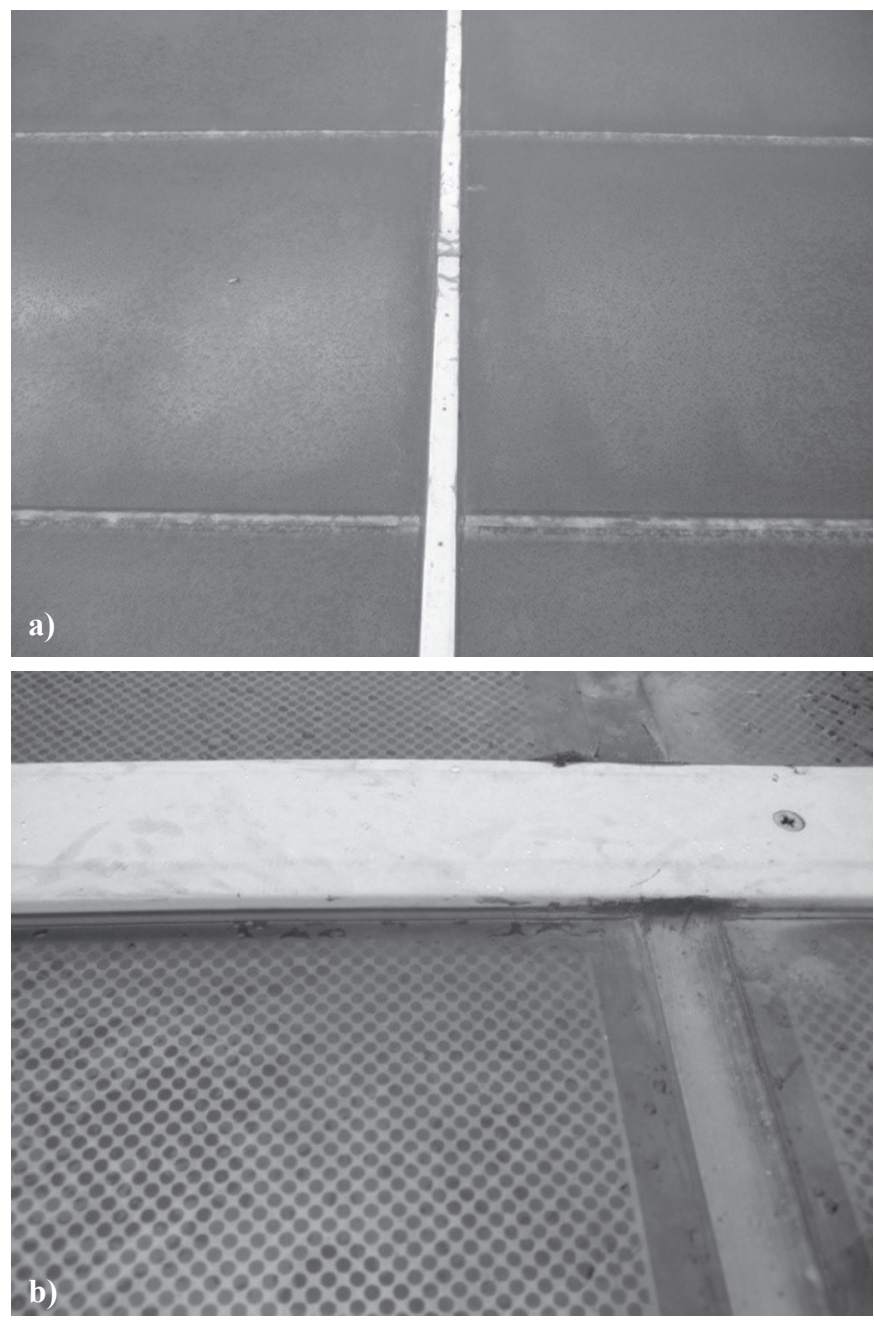

Obr. 4 Pohled na spádové lišty - nevhodně mechanicky kotvené bez možnosti utěsněni spoje: a) pohled na lištu nevhodně „utěsněnou “ b) detail ,utěsněné“ lišty tmelem.

Fig. 4 View of the ramps-inappropriately mechanically fixed without the possibility of sealing the joint: a) a view of the bar in an inappropriately ,, sealed“; b) detail of ,, sealed" moldingsseal.

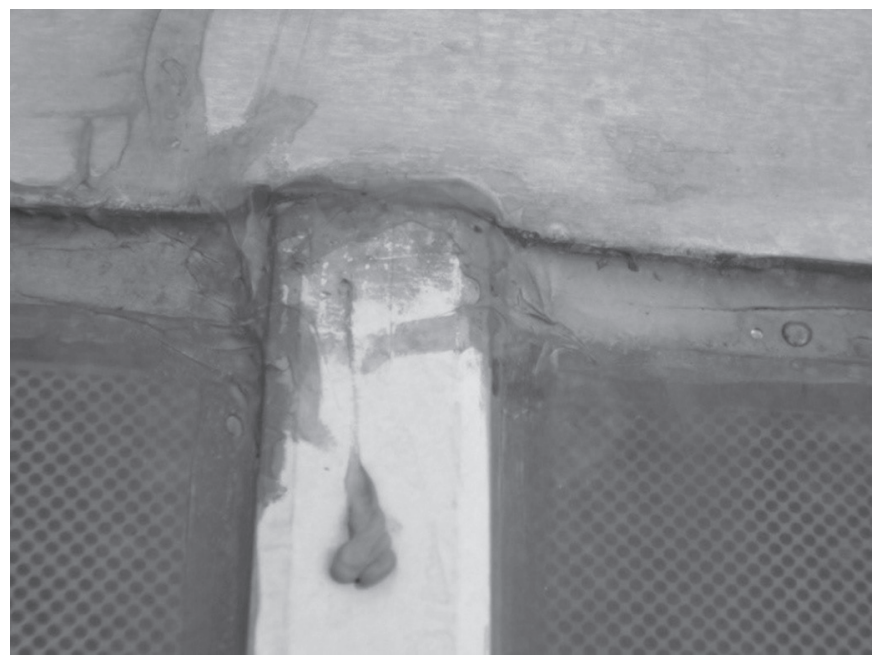

Obr. 5 Pohled na nevhodně „utěsněné“ oplechování tmelem. Fig. 5 A view of an inappropriate, ,sealed" tile picking. f) poruchy zasklívacích jednotek - zasklívací jednotky s poškozenou kalenou skleněnou vnější tabulí vlivem samoexploze, jejíž iniciace je patrná charakteristickým místem, kde se sloučenina NiS nacházela. Příčinou samoexploze jsou kulovité vměstky minerálu síranu nikelnatého. Sloučenina NiS prochází během kalení změnou krystalické mřížky a někdy zůstává v nestabilní formě. Součinitel tepelné roztažnosti NiS je větší, než součinitel tepelné roztažnosti skla. Tato kombinace je příčinou samovolného zničení kaleného skla bez zjevné př́činy. Samoexploze nastává někdy ihned a jindy po určité, i značně dlouhé době. Charakteristický lom rozbitého skla v důsledku př́měsí NiS vytvárí tzv. motýlka v místě, kde se sloučenina nacházela.
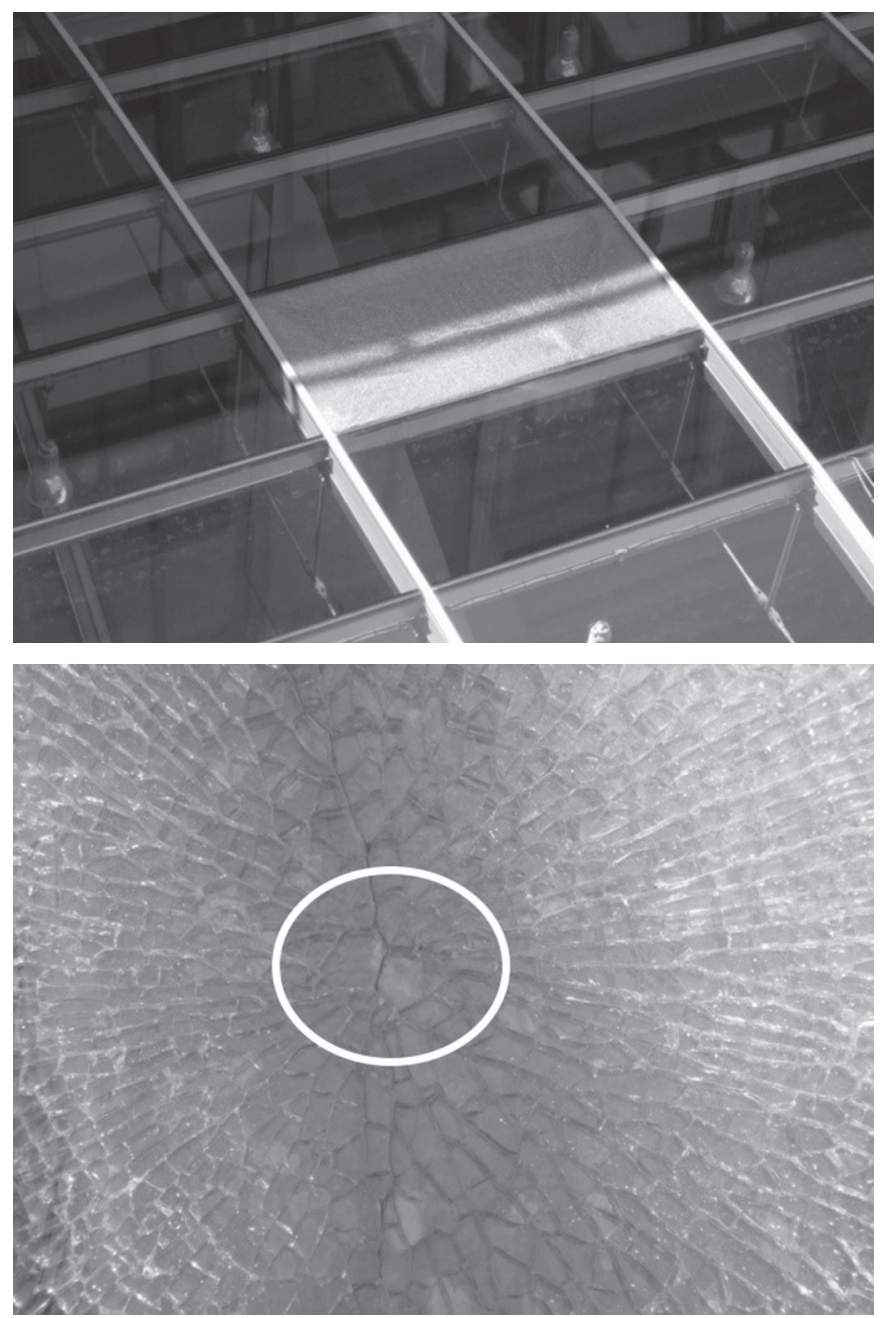

Obr. 6 pohled na porušenou zasklivací jednotku samoexplozi: a) pohled na prosklený střešni plášt; b) detail samoexploze.

Fig. 6 view of the self-explanation glazing unit: a) a view of the glass roof; b) detail of self-explanation.

\section{ZÁVĚR}

Na závěr lze říci, že návrh i realizace prosklených stř̌ešních plášt’ů musí být provedeny vždy komplexně a systematicky. Důležitý je bezchybný návrh střechy včetně všech detailů střešního pláště a jejich tepelně technické posouzení z hlediska funkčních 
požadavků s důrazem na odolnost konstrukce proti klimatickým zatížením.

\section{LITERATURA}

[1] ČSN 731901 Navrhováni střech-základni ustanovení, Český normalizační institut, Praha, 2011, 56 s.

[2] ETAG 002 - Systémy zaskleni s konstrukčním tmelem, Evropská organizace pro technická schválení, EOTA, Kunstlaan 40 Avenue es Arts B - 1040 Brussels, 2002, 13 s.

[3] ČSN 733610 Klempiŕrské práce stavební, Český normalizační institut, Praha, 2008, $72 \mathrm{~s}$

[4] Technické podklady fy Illbruck.

Správná citace:

ŠILAROVÁ, S.. Příčiny poruch prosklených střech. Soudní inženýrství, 2018, 29(3), 33-36. ISSN 1211-443X. 